\title{
Meningkatkan Self Efficacy Matematika Siswa Sekolah Menengah Pertama Melalui Model Pembelajaran Kooperatif Tipe NHT
}

\author{
Misnasanti ${ }^{*}$, Jailani ${ }^{2}$ \\ ${ }^{1}$ Pendidikan Guru Madrasah Ibtidaiyah, FKIP, Universitas Islam Negeri Antasari Banjarmasin, \\ Banjarmasin \\ 3 Pendidikan Matematika, FMIPA, Universitas Negeri Yogyakarta, Yogyakarta \\ *email: misna.santi@gmail.com
}

\begin{abstract}
The low mathematics self efficacy of junior high school students and the infrequency of teachers using learning models that can enhance students 'self efficacy in learning mathematics encourage researcher to conduct classroom action research aimed to increase students' mathematics self efficacy and to improve the quality of mathematics learning through NHT type of cooperative learning model. The population was all students of grade VII SMP 12 Yogyakarta and sample was students of class VII-D. Data collected by questionnaire, observation, field notes and tests. This research was said to be successful if the students' selfefficacy increase with moderate criteria reached $33.33 \%$ and the high criteria reached $53 \%$. Learning was said to be successful if there were at least $75 \%$ of students who complete with a passing grade minimal 75 . Learning worked well when the learning process reached 90\%. The results showed that learning using the NHT learning model can improve students' mathematics self efficacy. The average score of students' mathematics self efficacy questionnaire obtained from student questionnaire data has increased in each cycle. The implementation of learning has increased from cycle I which showed an average of $74 \%$ to cycle II with an average of $93 \%$. Cognitive test results obtained indicate an increase in cognitive test results from cycle I to cycle II.
\end{abstract}

Keywords: Mathematics Self Efficacy; NHT; Quality of Mathematics Learning

\begin{abstract}
Abstrak
Masih rendahnya self efficacy matematika siswa SMP dan masih jarangnya guru menggunakan model pembelajaran yang dapat menumbuhkan dan meningkatkan self efficacy siswa dalam belajar matematika mendorong peneliti untuk melakukan penelitian tindakan kelas yang bertujuan untuk meningkatkan self efficacy matematika siswa dan meningkatkan kualitas pembelajaran matematika melalui model pembelajaran kooperatif tipe NHT. Populasi dalam penelitian ini adalah semua siswa kelas VII SMP Negeri 12 Yogyakarta dengan sampel penelitian adalah siswa kelas VII-D. Data dikumpulkan dengan angket, observasi, catatan lapangan dan tes. Penelitian ini dikatakan berhasil jika self efficacy siswa meningkat dengan kriteria sedang mencapai 33,33\% dan kriteria tiggi mencapai 53\%. Pembelajaran dikatakan berhasil jika minimal terdapat $75 \%$ siswa yang tuntas dengan nilai ketuntasan $\geq 75$. Pembelajaran berhasil terlaksana dengan baik apabila proses pembelajaran mencapai 90\%. Hasil penelitian menunukkan bahwa pembelajaran menggunakan model pembelajaran NHT dapat meningkatkan self efficacy matematika siswa. Rata-rata skor angket self efficacy matematika siswa yang diperoleh dari data angket siswa mengalami peningkatan pada setiap siklus. Keterlaksanaan pembelajaran mengalami peningkatan dari siklus I yang menunjukkan ratarata $74 \%$ ke siklus II dengan rata-rata 93\%. Hasil tes kognitif yang diperoleh menunjukkan adanya peningkatan hasil tes kognitif dari siklus I ke siklus II.
\end{abstract}

Kata Kunci: Self Efficacy Matematika; NHT; Kualitas Pembelajaran Matematika 


\section{PENDAHULUAN}

Pembelajaran matematika di sekolah bukan semata-mata hanya menjadi upaya untuk mengenalkan matematika kepada siswa, tetapi juga merupakan suatu upaya untuk meningkatkan kemampuan berpikir siswa. Hal ini didukung dengan Permendikbud Nomor 21 Tahun 2016 yang menyebutkan bahwa tujuan pembelajaran matematika antara lain siswa menunjukkan sikap logis, kritis, analitis, kreatif, cermat dan teliti, bertanggung jawab, responsif, dan tidak mudah menyerah dalam memecahkan masalah. Namun peristiwa yang sering terjadi adalah siswa kurang aktif, kurang berpartisipasi dan terkesan hanya sebagai pendengar yang diinformasikan oleh guru, hal ini mempengaruhi pencapaian setiap materi yang diberikan pada waktu pembelajaran. Oleh karena itu, guru harus memahami apa yang dipikirkan oleh siswa sehingga dapat menjadi bahan evaluasi dalam proses pembelajaran. Hal ini sejalan dengan pernyataan Yates (2002) bahwa beberapa penelitian mengindikasikan berbagai sikap dan keyakinan siswa terhadap matematika mempengaruhi prestasi belajar matematika siswa tersebut.

Kebanyakan berbagai sikap dan keyakinan siswa terhadap matematika adalah menganggap bahwa matematika itu tidak mudah dan begitu kompleks sehingga banyak dari siswa merasa tidak yakin akan kemampuan dirinya dalam mempelajari matematika. Berkaitan dengan keyakinan diri siswa, Licht \& Krist (Schunk, 2012) berpendapat bahwa self efficacy merupakan keyakinan tentang apa yang mampu dilakukan seseorang. Tentu hal ini penting dan akan mempengaruhi hasil pencapaian siswa dalam pembelajaran.

Berdasarkan hasil observasi, ada salah satu kelas yang memiliki masalah dengan keyakinan diri dalam pembelajaran matematika di SMP Negeri 12 Yogyakarta, yaitu kelas VII-D. kebanyakan siswa tidak yakin akan kemampuan dirinya dalam menyelesaikan soal-soal matematika yang siswa hadapi, siswa lebih memilih diam ketika menghadapi materi yang kurang dipahami daripada bertanya kepada guru. Didukung dari hasil angket self efficacy yang diberikan kepada siswa sebagai pra-penelitian. Hasil angket self efficacy menunjukkan rata-rata self efficacy siswa tergolong pada kategori sedang dengan persentase 53,33\% dengan frekuensi 16 siswa dari total 30 siswa. Dan 10\% siswa atau sebanyak 3 siswa masih berada pada kategori rendah. Diduga keadaan ini didukung dengan model pembelajaran konvensional yang masih digunakan oleh guru, lebih cenderung dengan metode ceramah sehingga siswa kurang aktif dalam proses pembelajaran. Siswa sebagai pendengar setia sehingga kurang memunculkan sikap self efficacy dalam proses pembelajaran. 
Walaupun di SMP N 12 Yogyakarta telah menggunakan kurikulum 2013 namun guru masih belum menerapkan pembelajaran yang berbasis kurikulum 2013. Hasil wawancara dengan guru matematika, diperoleh informasi siswa tidak selalu dapat memahami apa yang disampaikan oleh guru. Siswa hanya menghapal konsep dan kurang mampu menggunakan konsep tersebut jika mengerjakan soal yang berbeda dengan contoh, siswa cenderung hanya menerima informasi yang disampaikan guru dan sulit untuk diikutsertakan dalam berpikir. Artinya, proses pembelajaran lebih banyak didominasi oleh guru. Hal ini disebabkan karena guru masih kesulitan dalam melaksanakan pembelajaran matematika.

Dengan pemaparan beberapa permasalahan di atas, menjadi tugas guru untuk membangkitkan keyakinan belajar siswa dan meningkatkan partisipasi mereka dengan cara menciptakan suasana belajar yang aktif dan menciptakan komunikasi dua arah. Guru harus bertindak sebagai fasilitator untuk membentuk dan mengembangkan pengetahuan, bukan untuk memindahkan pengetahuan.

Salah satu model pembelajaran yang dapat meningkatkan keaktifan dan keyakinan siswa untuk berkolaborasi dalam proses pembelajaran adalah model pembelajaran kooperatif tipe Numbered Head Together (NHT). Salah satu dari banyaknya teknik dalam model pembelajaran kooperatif yang memberikan kesempatan kepada siswa untuk saling berkomunikasi secara aktif dalam menyelesaikan tugas-tugas siswa. Model NHT tidak jauh berbeda dengan diskusi kelompok, karena didalamnya terjadi interaksi antar siswa untuk menyelesaikan tugas yang diberikan oleh guru sehingga mampu meningkatkan keyakinan siswa untuk berpartisipasi dalam proses pembelajaran matematika. Untuk melihat keberhasilan self efficacy siswa melalui model pembelajaran kooperatif tipe NHT, maka dilakukan penelitian tindakan kelas dengan judul "Meningkatkan Self Efficacy Matematika Siswa Sekolah Menengah Pertama Melalui Model Pembelajaran Kooperatif Tipe NHT". Adapun tujuan dalam penelitian ini adalah untuk meningkatkan self efficacy matematika siswa dan meningkatkan kualitas pembelajaran melalui model pembelajaran kooperatif tipe NHT.

\section{METODE}

Penelitian yang dilakukan adalah Penelitian Tindakan Kelas (PTK) yang dilakukan dengan menerapkan model pembelajaran Number Head Together (NHT) untuk meningkatkan self efficacy siswa. Masing-masing siklus dilaksanakan pada kompetensi dasar untuk mengukur indikator-indikator tertentu yang diturunkan dari kompetensi dasar tersebut. Pada akhir masing-masing siklus akan dilaksanakan tes dan pengisian angket self efficacy. Tes dilaksanakan dengan tujuan untuk mengukur pemahaman siswa pada masing-masing siklus dan pengisian angket self efficacy dilakukan dengan tujuan untuk mengetahui self efficacy siswa pada masing-masing siklus. 
Lokasi Penelitian Tindakan Kelas ini dilakukan di SMP Negeri 12 Yogyakarta sekolah yang beralamat di Jalan Tentara Pelaja No.9, Bumijo, Jetis, Kota Yogyakarta, Daerah Istimewa Yogyakarta. Subyek penelitian ini adalah siswa kelas VII-D yang berjumlah 34 orang yang terdiri dari jumlah siswa laki-laki sebanyak 15 siswa dan jumlah siswa perempuan sebanyak 19 siswa. Penelitian ini direncanakan dalam dua siklus, akan tetapi apabila hasil yang diperoleh belum memenuhi indikator keberhasilan yang telah ditetapkan, maka dilanjutkan untuk siklus berikutnya. Siklus akan berakhir jika hasil penelitian yang diperoleh sudah sesuai dengan indikator keberhasilan penelitian.

Teknik pengumpulan data yaitu dengan angket self efficacy siswa terhadap matematika, observasi untuk mengamati keterlaksanaan pembelajaran sesuai dengan sintaks model pembelajaran NHT yang terjadi di dalam kelas selama proses pembelajaran berlangsung, catatan lapangan sebagai data refleksi serta perubahan yang terjadi saat pembelajaran dikumpulkan dari catatan lapangan dan tes berupa data tentang ketercapaian kompetensi dan ketuntasan belajar siswa pada materi yang diajarkan dalam pembelajaran matematika dikumpulkan dari hasil pretes dan posttes dengan metode tes tertulis.

Analisis data yang digunakan dalam penelitian ini adalah analisis data secara deskriptif kualitatif dan didukung dengan analisis data secara kuantitatif.

Teknik analisis data untuk lembar observasi keterlaksanaan pembelajaran dilakukan dengan cara memberikan skor 1 untuk setiap aspek yang terlaksana dan skor 0 untuk setiap aspek yang tidak terlaksana. Selanjutnya dihitung persentase keterlaksanaan dengan rumus sebagai berikut.

$$
P=\frac{M}{T} \times 100 \%
$$

Keterangan :

$\mathrm{P} \quad$ : Presentase keterlaksanaan pembelajaran

M : Frekuensi item terlaksana

$\mathrm{T}$ : Total item keterlaksanaan pembelajaran

Deskripsi keterlaksanaan pembelajaran disajikan dalam Tabel 1.

Tabel 1. Kriteria Keterlaksanaan Pembelajaran

\begin{tabular}{cc}
\hline Interval (\%) & Kriteria \\
\hline $86-100$ & Sangat baik \\
\hline $71-85$ & Baik \\
\hline $56-70$ & Cukup baik \\
\hline $41-55$ & Kurang \\
\hline $0-40$ & Sangat Kurang \\
\hline
\end{tabular}

Kegiatan pembelajaran dapat dikatakan terlaksana dengan baik, jika berdasarkan 


\section{Mandalika Mathematics and Education Journal}

Volume 2 Nomor 2, Desember 2020

e-ISSN 2715-1190 | | p-ISSN 2715-8292

DOI: http://dx.doi.org/10.29303/jm.v2i2.1781

observasi keterlaksanaan pembelajaran, kriteria pembelajaran minimal berada dalam kategori baik. Analisis angket self efficacy dilakukan dengan menggunakan bantuan skala lima. Melalui skala lima ini akan diperoleh kriteria untuk setiap skor yang didapatkan siswa. Angket motivasi menggunanakan penilaian 1 sampai 5 dan mengandung pernyataan positif dan negatif. Pedoman penskoran yang digunakan untuk setiap pernyataan positif dan negatif adalah sebagai berikut.

Tabel 2. Kriteria Penilaian Pernyataan positif

\begin{tabular}{cc}
\hline Skor & Kategori \\
\hline 1 & Tidak pernah \\
\hline 2 & Jarang \\
\hline 3 & Kadang-kadang \\
\hline 4 & Sering \\
\hline 5 & Selalu \\
\hline
\end{tabular}

Tabel 3. Kriteria Penilaian Pernyataan negatif

\begin{tabular}{cc}
\hline Skor & Kategori \\
\hline 5 & Tidak pernah \\
\hline 4 & Jarang \\
\hline 3 & Kadang-kadang \\
\hline 2 & Sering \\
\hline 1 & Selalu \\
\hline
\end{tabular}

Teknik analisis data untuk angket self efficacy matematika dilakukan dengan cara menghitung skor angket siswa, menentukan kriteria hasil pengukuran, dan mengelompokkan siswa ke dalam beberapa kriteria tersebut. Kriteria hasil pengukuran ditentukan dengan perhitungan berdasarkan pendapat Widoyoko (2009). Adapun kriteria yang dihasilkan dari perhitungan tersebut dapat dilihat pada Tabel 4.

Tabel 4. Klasifikasi Self Efficacy

\begin{tabular}{cccc}
\hline No. & Interval & Skor $(\mathrm{X})$ & Kriteria \\
& & $126<\mathrm{X}$ & Sangat Tinggi \\
\hline 1 & $\mathrm{Mi}+1,8 \mathrm{Si}<\mathrm{X}$ & $102<\mathrm{X} \leq 126$ & Tinggi \\
\hline 2 & $\mathrm{Mi}+0,6 \mathrm{Si}<\mathrm{X} \leq \mathrm{Mi}+1,8 \mathrm{Si}$ & $78<\mathrm{X} \leq 102$ & Sedang \\
\hline 3 & $\mathrm{Mi}-0,6 \mathrm{Si}<\mathrm{X} \leq \mathrm{Mi}+0,6 \mathrm{Si}$ & $54<\mathrm{X} \leq 78$ & Rendah \\
\hline 4 & $\mathrm{Mi}-1,8 \mathrm{Si}<\mathrm{X} \leq \mathrm{Mi}-0,6 \mathrm{Si}$ & $\mathrm{X} \leq 54$ & Sangat Rendah \\
\hline 5 & $\mathrm{X} \leq \mathrm{Mi}-1,8 \mathrm{Si}$ & & (Widoyoko, 2009)
\end{tabular}

Keterangan:

$\mathrm{Mi}=$ Mean ideal yang dapat dicapai instrumen $=1 / 2$ (skor tertinggi + skor terendah $)$

$\mathrm{Si}=$ Standar deviasi ideal yang dapat dicapai instrumen $=1 / 6$ (skor tertinggi-skor terendah) 
Teknik analisis data untuk tes dilakukan dengan cara memberikan skor pada jawaban setiap siswa, yaitu skor 1 untuk jawaban benar dan skor 0 untuk jawaban salah. Setelah itu dilakukan perhitungan untuk mengetahui nilai setiap siswa dengan menggunakan rumus sebagai berikut.

Persentase $(P)=\frac{\text { Jumlah Skor Keseluruhan Yang Diperoleh Siswa }}{\text { Jumlah Siswa }} \times 100 \%$

Penelitian ini dikatakan berhasil jika self efficacy siswa meningkat dengan kriteria sedang mencapai 33,33\% dan kriteria tiggi mencapai 53\%. Berdasarkan hasil belajar matematika, pembelajaran dikatakan berhasil jika minimal terdapat $75 \%$ siswa yang tuntas dengan nilai ketuntasan $\geq 75$ sesuai dengan KKM yang dtetapkan oleh Sekolah. Berdasarkan keterlaksanaan pembelajaran, pembelajaran berhasil terlaksana dengan baik apabila proses pembelajaran menggunakan model pembelajaran kooperatif tipe Number Head Together mencapai 90\%.

\section{HASIL DAN PEMBAHASAN}

Target peningkatan self efficacy siswa kelas VIII-B dalam penelitian ini adalah sebagai berikut.

Tabel 5. Target Pencapaian Self Efficacy Siswa Kelas VII-D

\begin{tabular}{|c|c|c|c|c|}
\hline Variabel & Interval & Kriteria & Kondisi Awal & Target \\
\hline \multirow{6}{*}{ Self Efficacy } & $126<\mathrm{X}$ & Sangat Tinggi & $0.00 \%$ & $\begin{array}{l}13,30 \% \quad(4 \\
\text { siswa) }\end{array}$ \\
\hline & $102<\mathrm{X} \leq 126$ & Tinggi & $\begin{array}{l}36,67 \% \\
\text { siswa) }\end{array}$ & $\begin{array}{ll}53 \% & (16 \\
\text { siswa) } & \end{array}$ \\
\hline & $78<\mathrm{X} \leq 102$ & Sedang & $\begin{array}{l}53,33 \% \\
\text { siswa) }\end{array}$ & $\begin{array}{l}33,33 \% \quad(10 \\
\text { siswa) }\end{array}$ \\
\hline & $54<X \leq 78$ & Rendah & $10 \%$ (3 siswa) & $0.00 \%$ \\
\hline & $\mathrm{X} \leq 54$ & Sangat Rendah & $0.00 \%$ & $0.00 \%$ \\
\hline & Rata-rata $=97,83$ & Sedang & sedang & tinggi \\
\hline \multirow{2}{*}{$\begin{array}{l}\text { Kognitif/ } \\
\text { keterampilan }\end{array}$} & yang tuntas $\geq 75 \%$ & KKM tercapai & $0 \%$ & $75 \%$ \\
\hline & Rata-rata $=75$ & 75 & 1,2 & 77 \\
\hline $\begin{array}{l}\text { Proses } \\
\text { Pembelajaran }\end{array}$ & terlaksana $\geq 90 \%$ & Pemb. Berhasil & & $\geq 90 \%$ \\
\hline
\end{tabular}

\subsection{Deskripsi Pelaksanaan Siklus I}

Siklus I dilaksanakan sebanyak tiga kali pertemuan untuk penyampaian materi. Pada pertemuan pertama siswa mempelajari materi mengenai bentuk aljabar dari suatu masalah kontekstual dan menentukan hasil penjumlahan bentuk aljabar, sedangkan pada pertemuan kedua siswa mempelajari materi menentukan hasil dari pengurangan dan perkalian bentuk aljabar. Pada pertemuan ketiga siswa mempelajari menentukan 
hasil pembagian dan faktorisasi bentuk aljabar. Pada pertemuan keempat dilakukan tes evaluasi siklus I. Adapun keterlaksanaan pembelajaran siklus I dapat dilihat pada penyajian data berikut.

Tabel 6. Hasil Observasi Pembelajaran Selama Siklus I

\begin{tabular}{|c|c|c|c|}
\hline Pertemuan & $\begin{array}{l}\text { Presentase Aktivitas } \\
\text { Guru }\end{array}$ & $\begin{array}{l}\text { Presentase Aktivitas } \\
\text { Siswa }\end{array}$ & Rata-Rata \\
\hline 1 & $60 \%$ & $56 \%$ & $58 \%$ \\
\hline 2 & $88 \%$ & $68 \%$ & $78 \%$ \\
\hline \multirow[t]{2}{*}{3} & $88 \%$ & $84 \%$ & $86 \%$ \\
\hline & Siklus 1 & & $74 \%$ \\
\hline
\end{tabular}

Berdasarkan tabel diatas dapat disimpulkan bahwa keterlaksanaan pembelajaran belum mencapai target yaitu 90\% sehingga keterlaksanaan pembelajaran masih belum optimal atau belum baik sehingga diperlukan refleksi dan perbaikan pada siklus selanjutnya. Setelah berakhirnya siklus pertama, maka dilakukan postest siklus I untuk mengukur pencapaian kompetensi dan sejauh mana penguasaan siswa tentang materi yang telah diajarkan. Adapun berbandingan hasil pretesrt dan postest pada siklus 1 yang diperoleh dapat dilihat pada Tabel 7 .

Table 7. Hasil Pretes dan Posttes Siklus I

\begin{tabular}{ccccc}
\hline Ketuntasan Siswa & \multicolumn{2}{c}{ Pretest } & \multicolumn{2}{c}{ Postest Siklus 1 } \\
\cline { 2 - 5 } & Jumlah siswa & Persentase & $\begin{array}{c}\text { Jumlah } \\
\text { siswa }\end{array}$ & Persentase \\
\hline Tuntas & 0 & $0 \%$ & 10 & $33,33 \%$ \\
\hline Tidak Tuntas & 30 & $100 \%$ & 20 & $66,67 \%$ \\
\hline Rata-rata skor kelas & \multicolumn{2}{c}{1,2} & \multicolumn{2}{c}{ Tidak Tuntas } \\
\hline Ketuntasan Kelas & \multicolumn{2}{c}{ Tidak Tuntas } & \multicolumn{2}{c}{} \\
\hline
\end{tabular}

Berdasarkan tabel di atas, dapat disimpulkan bahwa ketuntasan siswa dari pretest $0 \%$, artinya tidak ada satupun siswa yang mencapai target KKM individu 75. Pada postest siklus pertama diperoleh hasil 33,33\% atau 10 siswa yang tuntas mencapai KKM namun ketuntasan kelas belum tercapai yakni 75\% siswa mencapai target KKM. Namun secara umum terjadi peningkatan dari pretes ke siklus I yakni peningkatan keuntasan siswa sebesar 33,33\% walaupun belum mencapai target sehingga diperlukan refleksi untuk memperbaiki pembelajaran pada siklus II.

Pada data hasil self efficacy matematika siswa siklus I pula diperoleh peningkatan yakni dari 97,83\% meningkat menjadi 107,57\%yang sudah berada pada kategori tinggi. Adapun data hasil self efficacy siklus I disajikan pada Tabel 8. 


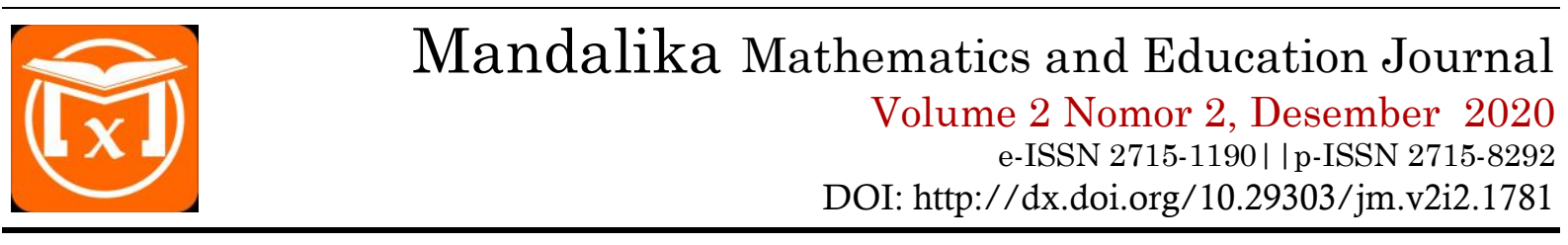

Tabel 8. Hasil Self Efficacy Matematika Siswa Siklus I

\begin{tabular}{llllll}
\hline Variabel & Interval & Kriteria & $\begin{array}{l}\text { Kondisi } \\
\text { Awal }\end{array}$ & Target & Siklus I \\
\hline \multirow{4}{*}{$\begin{array}{l}\text { Self } \\
\text { Efficacy }\end{array}$} & $126<\mathrm{X}$ & $\begin{array}{l}\text { Sangat } \\
\text { Tinggi }\end{array}$ & $0 \%$ & $13.30 \%$ & $0 \%$ \\
\cline { 2 - 6 } & $102<\mathrm{X} \leq 126$ & Tinggi & $36,67 \%$ & $53 \%$ & $38,24 \%$ \\
\cline { 2 - 6 } & $\begin{array}{l}78<\mathrm{X} \leq 102 \\
54<\mathrm{X} \leq 78\end{array}$ & Sedang & $53,33 \%$ & $33,33 \%$ & $61,76 \%$ \\
\cline { 2 - 6 } & $\mathrm{X} \leq 54$ & $\begin{array}{l}\text { Rendah } \\
\text { Rendah }\end{array}$ & $10 \%$ & $0 \%$ & $0 \%$ \\
\hline \multirow{2}{*}{ Rata-rata } & & - & $\begin{array}{l}\text { Sedang } \\
(97,83)\end{array}$ & $\begin{array}{l}\text { Tinggi } \\
(102<\mathrm{X} \\
\leq 126)\end{array}$ & $\begin{array}{l}\text { Tinggi } \\
(107,57)\end{array}$ \\
\hline
\end{tabular}

Pada evaluasi siklus 1 hanya diikuti 33 dari 34 siswa. Ada 1 siswa yang tidak ikut tes, namun peneliti menyamakan jumlah siswa yang akan dihitung tingkat self efficacy dan hasil posttest nya pada setiap siklus agar dapat melihat persentase kenaikan dari siklus 1 ke siklus 2 dengan lebih mudah dengan jumlah frekuensi siswa yang sama.

Dilihat dari tabel di atas, rata-rata keseluruhan aktivitas guru dan siswa pada siklus 1 belum mencapai target, yaitu hanya 74\%. Dilihat dari tes kognitif yaitu hasil dari tes postes, siswa yang mencapai KKM sebanyak 10 orang atau 33,33\%, sedangkan sebanyak 20 siswa atau 66,67\% dari 30 siswa belum mencapai KKM. Hasil penyebaran angket, self efficacy siswa pada siklus 1 meningkat yang mana self efficacy siswa pada kondisi awal $36,67 \%$ pada kategori tinggi dan 53,33, dan masih ada $10 \%$ siswa yang berada pada kategori rendah. Pada siklus 1 self efficacy dengan 38,24\% kategori tinggi dan 61,76\% kategori sedang. Tidak ada lagi siswa yang berada pada kategori rendah, namun belum ada siswa yang ada dikategori sangat tinggi. Selain itu persentase siswa yang self efficacy nya yang berada pada kategori tinggi dan sedang juga belum mencapai target. Sehingga masih belum mencapai target pencapaian. Dapat disimpulkan pembelajaran siklus 1 belum dikatakan berhasil karena belum memenuhi nilai indikator pencapaian yang ditetapkan.

\subsection{Deskripsi Pelaksanaan Tindakan Siklus II}

Siklus II dilaksanakan sebanyak dua kali pertemuan dengan materi menyelesaikan masalah yang berkaitan dengan bentuk aljabar dan operasi pada bentuk aljabar. Siswa mempelajari materi menentukan penyelesaian masalah dari soal cerita yang berkaitan dengan bentuk aljabar dengan menggunakan operasi hitung penjumlahan dan pengurangan pada bentuk aljabar. Sedangkan pada pertemuan kedua siswa mempelajari tentang menentukan penyelesaian masalah dari soal cerita yang berkaitan dengan bentuk aljabar dengan menggunakan operasi hitung perkalian dan pembagian pada bentuk aljabar. Pada pertemuan ketiga dilakukan tes evaluasi II. 


\section{Mandalika Mathematics and Education Journal}

Volume 2 Nomor 2, Desember 2020

e-ISSN 2715-1190 | | p-ISSN 2715-8292

DOI: http://dx.doi.org/10.29303/jm.v2i2.1781

Secara keseluruhan, observasi keterlaksanaan pembelajaran siklus II adalah sebagai berikut.

Tabel 9. Persentase Aktivitas Guru dan Siswa Siklus II

\begin{tabular}{cccc}
\hline Pelaksanaan & $\begin{array}{c}\text { Presentase } \\
\text { Aktivitas Guru }\end{array}$ & $\begin{array}{c}\text { Presentase } \\
\text { Aktivitas Siswa }\end{array}$ & Rata-Rata \\
\hline Pertemuan ke-1 & $92 \%$ & $84 \%$ & $88 \%$ \\
\hline Pertemuan ke-2 & $100 \%$ & $96 \%$ & $98 \%$ \\
\hline & Siklus II & & $93 \%$ \\
\hline
\end{tabular}

Berdasarkan tabel diatas dapat disimpulkan bahwa keterlaksanaan pembelajaran mencapai target yaitu $93 \%$ keterlaksanaan pembelajaran dikatakan sudah optimal atau baik.

Pada data hasil self efficacy matematika siswa siklus II pula diperoleh peningkatan dibanding dengan siklus 1 . Hal ini terlihat darimpeningkatan pada kategori sangat tinggi dan tinggi, sedangkan persentase kategori sedang mengalami penurunan. Adapun data hasil self efficacy siklus II disajikan pada Tabel 10.

Tabel 10. Hasil Self Efficacy Matematika Siswa Siklus II

\begin{tabular}{llllll}
\hline Variabel & Interval & Kriteria & $\begin{array}{l}\text { Kondisi } \\
\text { Awal }\end{array}$ & Target & Siklus II \\
\hline \multirow{3}{*}{$\begin{array}{l}\text { Self } \\
\text { Efficacy }\end{array}$} & $\begin{array}{l}\text { Sangat } \\
\text { Tinggi }\end{array}$ & $0 \%$ & $13,30 \%$ & $16,67 \%$ \\
\cline { 2 - 6 } & $102<\mathrm{X} \leq 126$ & Tinggi & $36,67 \%$ & $53 \%$ & $70 \%$ \\
\cline { 2 - 6 } & $\begin{array}{l}78<\mathrm{X} \leq 102 \\
54<\mathrm{X} \leq 78\end{array}$ & Sedang & $53,33 \%$ & $30 \%$ & $13 \%$ \\
\cline { 2 - 6 } & $\mathrm{X} \leq 54$ & $\begin{array}{l}\text { Rendah } \\
\text { Rendah }\end{array}$ & $10 \%$ & $0 \%$ & $0 \%$ \\
\hline \multirow{2}{*}{ Rata-rata } & & - & $\begin{array}{l}\text { Sedang } \\
(97,83)\end{array}$ & $\begin{array}{l}\text { Tinggi } \\
(102<\mathrm{X} \\
\leq 126)\end{array}$ & $\begin{array}{l}\text { Tinggi } \\
(112,67)\end{array}$ \\
\hline
\end{tabular}

Adapun perbandingan hasil postest pada siklus I dan siklus II yang diperoleh dapat dilihat pada Tabel 11 .

Tabel 11. Hasil Posttes Siklus II

\begin{tabular}{ccccc}
\hline \multirow{2}{*}{$\begin{array}{c}\text { Ketuntasan } \\
\text { Siswa }\end{array}$} & \multicolumn{2}{c}{ Pretest } & \multicolumn{2}{c}{ Postest Siklus 1I } \\
\cline { 2 - 5 } & Jumlah siswa & Persentase & $\begin{array}{c}\text { Jumlah } \\
\text { siswa }\end{array}$ & Persentase \\
\hline Tuntas & 0 & $0 \%$ & 24 & $80 \%$ \\
\hline Tidak Tuntas & 30 & $100 \%$ & 6 & $20 \%$ \\
\hline $\begin{array}{c}\text { Rata-rata skor } \\
\text { kelas }\end{array}$ & 10,4 & & 82,67 & \\
\hline
\end{tabular}




\begin{tabular}{|c|c|c|c|c|}
\hline \multirow{2}{*}{$\begin{array}{l}\text { Ketuntasan } \\
\text { Siswa }\end{array}$} & \multicolumn{2}{|c|}{ Pretest } & \multicolumn{2}{|c|}{ Postest Siklus 1I } \\
\hline & Jumlah siswa & Persentase & $\begin{array}{c}\text { Jumlah } \\
\text { siswa }\end{array}$ & Persentase \\
\hline $\begin{array}{c}\text { Ketuntasan } \\
\text { Kelas }\end{array}$ & \multicolumn{2}{|c|}{ Tidak Tuntas } & \multicolumn{2}{|c|}{ Tuntas } \\
\hline
\end{tabular}

Berdasarkan table di atas, dapat disimpulkan bawha ketuntasan siswa siklus II mengalami peningkatan serta telah mencapai target KKM individu 75 begitu pula dengan KKM kelas yakni 75\% siswa mencapai KKM. Pada postes siklus II diperoleh hasil $82,67 \%$ atau 24 siswa mencapai target KKM sehingga penelitian terhenti pada siklus II. Berikut disajikan rekapitulasi hasil siklus I dan siklus II pada Tabel 12.

Tabel 12. Rekapitulasi Hasil Siklus I dan Siklus II

\begin{tabular}{|c|c|c|c|c|c|c|}
\hline Variabel & Interval & Kriteria & $\begin{array}{c}\text { Kondisi } \\
\text { Awal }\end{array}$ & Target & $\begin{array}{c}\text { Akhir } \\
\text { Siklus } 1\end{array}$ & $\begin{array}{c}\text { Akhir } \\
\text { Siklus } 2\end{array}$ \\
\hline \multirow{6}{*}{$\begin{array}{c}\text { Self } \\
\text { Efficacy }\end{array}$} & $126<X$ & $\begin{array}{c}\text { Sangat } \\
\text { Tinggi }\end{array}$ & $0 \%$ & $\begin{array}{c}13,30 \% \\
\text { (4 siswa) }\end{array}$ & $\begin{array}{c}6,67 \%(2 \\
\text { siswa) }\end{array}$ & $\begin{array}{c}16,67 \% \\
(5 \text { siswa) }\end{array}$ \\
\hline & $102<X \leq 126$ & Tinggi & $\begin{array}{c}36,67 \% \\
(11 \text { siswa) }\end{array}$ & $\begin{array}{c}53 \%(16 \\
\text { siswa) }\end{array}$ & $\begin{array}{c}63 \% \\
\text { (19 siswa) }\end{array}$ & $\begin{array}{c}70 \% \\
(21 \text { siswa) }\end{array}$ \\
\hline & $78<X \leq 102$ & Sedang & $\begin{array}{c}53 \% \\
(16 \text { siswa) }\end{array}$ & $\begin{array}{l}33,33 \% \\
(10 \\
\text { siswa) }\end{array}$ & $\begin{array}{c}30 \% \\
\text { (9 siswa) }\end{array}$ & $\begin{array}{c}13 \% \\
(4 \text { siswa) }\end{array}$ \\
\hline & $54<X \leq 78$ & Rendah & $\begin{array}{l}10 \%(3 \\
\text { siswa) }\end{array}$ & $0 \%$ & $0 \%$ & $0 \%$ \\
\hline & $X \leq 54$ & $\begin{array}{l}\text { Sangat } \\
\text { Rendah }\end{array}$ & $0 \%$ & $0 \%$ & $0 \%$ & $0 \%$ \\
\hline & $\begin{array}{c}\text { Rata-rata }= \\
93,21\end{array}$ & Sedang & $0 \%$ & tinggi & $\begin{array}{l}107,57 \\
\text { (tinggi) }\end{array}$ & $\begin{array}{l}112,67 \\
\text { (tinggi) }\end{array}$ \\
\hline \multirow[t]{2}{*}{$\begin{array}{l}\text { Kognitif/ket } \\
\text { erampilan }\end{array}$} & $\begin{array}{c}\text { yang tuntas } \\
\geq 75 \%\end{array}$ & $\begin{array}{c}\text { KKM } \\
\text { tercapai } \\
75 \\
\end{array}$ & $0 \%$ & $80 \%$ & $\begin{array}{c}33,33 \% \\
(9 \text { siswa) }\end{array}$ & $\begin{array}{c}80 \% \\
\text { (2siswa) }\end{array}$ \\
\hline & Rata-rata & 75 & 1,2 & 75 & 67,73 & 82,67 \\
\hline $\begin{array}{c}\text { Proses } \\
\text { Pembelajar } \\
\text { an }\end{array}$ & $\begin{array}{c}\text { terlaksana } \\
\geq 90 \% \\
\end{array}$ & $\begin{array}{c}\text { Pemb } \\
\text { Berhasil }\end{array}$ & $0 \%$ & $90 \%$ & $71,33 \%$ & $93 \%$ \\
\hline
\end{tabular}

Dari Tabel 12 terlihat bahwa hasil angket yang mengukur self efficacy matematika siswa di siklus I mengalami peningkatan dari 107,57 menjadi 112,67 di siklus II. Peningkatan terjadi di setiap kategori. Untuk kategori siswa berkemampuan sangat tinggi dari siklus I yaitu $6,67 \%$ menjadi $16,67 \%$ di siklus II. Untuk kategori tinggi mengalami peningkatan dari siklus I yaitu 63\% menjadi 70\%. Hasil di kategori sedang menurun dari yang awalnya $30 \%$ di siklus I menjadi $13 \%$ di siklus II.

Selain itu peningkatan juga terjadi untuk nilai rata-rata siswa. Dari siklus I mengalami peningkatan dari rata-rata 67,73 pada siklus I meningkat menjadi 82,67 pada siklus II. 
Selain itu pada siklus I persentase siswa yang mencapai nilai KKM (diatas 75) belum mencapai $70 \%$ yaitu hanya $33,33 \%$, sedangkan pada siklus II persentase telah mencapai target $\geq 70 \%$ yaitu $80 \%$. Dari uraian tersebut dapat dikatakan bahwa self efficacy matematika dan prestasi siswa kelas VII D SMP Negeri 12 Yogyakarta mengalami peningkatan dari siklus I ke siklus II.

Berdasarkan hasil observasi keterlaksanaan pembelajaran, pembelajaran matematika menggunakan model Number Head Together (NHT) sudah terlaksana dengan baik. Ratarata persentase hasil observasi keterlaksanaan pembelajaran pada pertemuan 1 dan 2 dan 3 di siklus I berturut-turut adalah 58\%, 78\% dan 86\% berdasarkan keterlaksanaan guru dan siswa dengan rata-rata mencapai $74 \%$. Hasil ini belum mencapai target yang ditetapkan yaitu $\geq 90 \%$. Pada siklus II telah mencapai persentase di atas $90 \%$, dengan hasil persentase di pertemuan 1 dan 2 sama-sama berturut-turut adalah 88\% dan 98\% dengan rata-rata mencapai $93 \%$. Jadi dapat disimpulkan bahwa penerapan pembelajaran matematika menggunakan model pembelajaran Number Head Together (NHT) telah terlaksana dengan baik dan cocok untuk diterapkan di kelas VII-D SMP N 12 Yogyakarta. Penelitian ini sejalan dengan penelitian sebelumnya oleh Hina Gita (2015) dengan judul "Penerapan Model Pembelajaran Kooperatif Tipe Numbered Head Together untuk Meningkatkan Self Efficacy Siswa”.

Hasil penelitian diperoleh proses pembelajaran mengalami perkembangan dari siklus I ke siklus II. Penelitian yang sejenis juga telah dilakukan Maratu Shalikhah (2015) yang berjudul "Eksperimentasi Model Pembelajaran Kooperatif Tipe Numbered Heads Together (NHT) dan Structured Numbered Heads (SNH) dengan Pendekatan Saintifik pada Materi Himpunan ditinjau dari Self Efficacy Siswa Kelas VII SMP Negeri seKabupaten Bantul Tahun Pelajaran 2014/2015”. Hasil penelitian menjelaskan bahwa pada model NHT dengan pendekatan saintifik, prestasi belajar matematika siswa self efficacy tinggi sama dengan siswa self efficacy sedang, dan prestasi belajar matematika siswa self efficacy tinggi lebih baik daripada siswa self efficacy rendah, dan prestasi belajar matematika siswa self efficacy tinggi sama dengan siswa self efficacy sedang dan prestasi belajar matematika siswa self efficacy tinggi sama dengan siswa self efficacy rendah.

\section{PENUTUP}

Berdasarkan hasil penelitian dan pembahasan yang telah diuraikan, maka diperoleh kesimpulan bahwa pembelajaran menggunakan model pembelajaran Number Head Together dapat meningkatkan self efficacy matematika siswa dan penerapan pembelajaran matematika menggunakan model pembelajaran kooperatif tipe NHT telah terlaksana dengan baik dan cocok untuk diterapkan di kelas VII-D SMP N 12 Yogyakarta. 
Hasil penelitian ini digunakan sebagai masukan dan refleksi bagi guru, calon guru, maupun penelitian selanjutnya dalam melaksanakan pembelajaran untuk dapat memperhatikan metode belajar yang tepat untuk meningkatkan prestasi belajar dan self efficacy siswa.

\section{REFERENSI}

Permendikbud. (2016). Salinan Peraturan Menteri Pendidikan dan Kebudayaan Republik Indonesia Nomor 21 Tahun 2016 tentang Standar Isi Pendidikan Dasar dan Menengah.

Schunk, D. (2012). Teori-teori Pembelajaran: Perspektif Pendidikan. (Translated by Eva Hamdiah dan Rahmat Fajar). Yogyakarta: Pustaka Pelajar.

Widoyoko, S.E.P. (2009). Evaluasi Program Pembelajaran: Panduan Praktis bagi Guru dan Calon Pendidik. Yogyakarta: Pustaka Belajar

Yates. (2002). The Influence of optimism and pemission on student achievement in mathematics. Mathematics Education Research Jornnal, 14(1),4-15. 